\title{
IDENTIFICATION OF FACTORS AND GROUPS AT RISK OF INFECTION WITH SCHISTOSOMA MANSONI: A STRATEGY FOR THE IMPLEMENTATION OF CONTROL MEASURES?
}

\author{
Pedro COURA-FILIIO, Roberto Sena ROCHA, Marcio Willian FARAII, Grace Carolina da SILVA \& Naftale KATZ
}

\begin{abstract}
SUMMARY
A fourteen year schistosomiasis control program in Peri-Peri (Capim Branco, MG) reduced prevalence from 43.5 to $4.4 \%$; incidence from 19.0 to $2.9 \%$, the geometric mean of the number of eggs from 281 to 87 and the level of the hepatoesplenic form cases from 5.9 to $0.0 \%$. In 1991, three years after the interruption of the program, the prevalence had risen to $19.6 \%$.

The district consists of Barbosa (a rural area) and Peri-Peri itself (an urban area). In 1991, the prevalence in the two areas was $28.4 \%$ and $16.0 \%$ respectively. A multivariate analysis of risk factors for schistosomiasis indicated the domestic agricultural activity with population attributive risk (PAR) of $29.82 \%$, the distance $(<10 \mathrm{~m})$ from home to water source (PAR $=25.93 \%$ ) and weekly fishing (PAR $=17.21 \%$ ) as being responsible for infections in the rural area. The recommended control measures for this area are non-manual irrigation and removal of homes to more than ten meters from irrigation ditches. In the urban area, it was observed that swimming at weekly intervals $(P A R=20.71 \%)$, daily domestic agricultural activity $(\mathrm{PAR}=4.07 \%)$ and the absence of drinking water in the home $(\mathrm{PAR}=4.29 \%)$ were responsible for infections. Thus, in the urban area the recommended control measures are the substitution of manual irrigation with an irrigation method that avoids contact with water, the creation of leisure options of the population and the provision of a domestic water supply. The authors call attention to the need for the efficacy of multivariate analysis of risk factors to be evaluated for schistosomiasis prior to its large scale use as a indicator of the control measures to be implemented.
\end{abstract}

KEYWORDS: Schistosomiasis control-Brazil; Risk factors.

\section{INTRODUCTION}

Because of existing epidemiological data compiled since 1974, the opportunity exists in Peri-Peri (Capim Branco, MG) of both identifying risk factors associated with schistosomiasis and also of subsequently impplementing control measures. A schistosomiasis control program has been undertaken in this district that involved annual specific treatment with oxamniquine and three monthly applications of niclosamide in water sources containing snails $8,9,15$. The fourteen years of the program resulted in important changes, reducing the prevalence of the disease from 43.5 to $4.4 \%$, the incidence from 19 to $2.9 \%$, the number of snails shedding cercariae from 14.3 to $1.5 \%$, the number of individuals with the hepatosplenic (HE) form of the disease from 5.9 to $0 \%$ and with the hepatointestinal (HI) form from 28.5 to $0 \%$. The program also eliminated the appearance of new HE cases during the period of the study ${ }^{9}$. Three years after the interruption of the program the prevalence amongst the residents returned to $19.6 \%$, showing that the population was still at risk of infection with 
Schistosoma mansoni. A study undertaken in the sixth year of the project aimed at explaining continued transmission showed that infected individuals (those eliminating eggs in their feces), had daily contact with streams and that, during the year study, the level of their contact was 4.5 times greater than that of non-infected individuals.

The ability to reduce the levels of specific indicators for schistosomiasis (prevalence, incidence, intensity of infection and clinical forms) in an endemic area by means of specific treatment has been proven; however, interruption of the control measures results in the exposed population been reinfected. The challenge is to prevent the disease indicators from returning to the initial levels by permanently reducing or interrupting parasite transmission in the endemic area. To achieve this, it is necessary to alter the dynamics of transmission principally in areas with local transmission such as those studied here.

Thus, it was considered both opportune and necessary to identify the determining factors for the transmission of schistosomiasis infection in the district of PeriPeri. In addition, the study includes the determination of the population attributable risk (PAR) for each risk factor for infection with $S$. mansoni.

\section{MATERIAL AND METHODS}

\section{Study Area}

Peri-Peri, a district of Capim Branco, Minas Gerais State, had at the start of the program (1974) a population of approximately 650 inhabitants. The region is situated approximately $61 \mathrm{Km}$ northeast of Belo Horizonte, MG, and consists of small holdings from 1 to 5 hectares irrigated by the river Ribeirão da Mata which provides water for the irrigation ditches for vegetable cultivation. The district is formed by two areas: Barbosa and PeriPeri. Barbosa has rural characteristics ${ }^{25}: 79.6 \%$ of the homes have wells, which become flooded in the rainy season; $75.0 \%$ of the active labor force are engaged in casual agricultural work (including women and children) and there are no telephone or urban transport systems. Peri-Peri has more urban characteristics ${ }^{25}$ : $75.9 \%$ of the homes have piped drinking water; $81.0 \%$ of the labor force are engaged in formal unionized employment within textile industries, coffee roasting and metal processing industries in the region; there are both telephone and urban transport systems. The prevalence of the disease in Barbosa at the start of the program (1974), at the end (1987) and in 1991 was 34.7, 4.2 and $28.4 \%$ respectively and in Peri-Peri 50.8, 3.0 and $16.0 \%$ respectively.

\section{Population survey}

Individuals who sleep at home during the week were considered as being residents. All the residents were listed and received a number and each home was assigned an identification number. A map was made that identified all the roads in each area. Children of less than one year of age, individuals receiving long term hospital treatment and paralytics were not included in the survey since there are not exposed to the infection with $S$. mansoni.

\section{Fecal examination}

Diagnosis was undertaken in 1991 using the quantitative Kato-Katz method ${ }^{15}$. The arithmetic mean of the number of $S$. mansoni eggs per gram of feces (epg) found in two slides from a single fecal sample was taken as a measure of intensity of infection in individuals. For the measurement of the intensity of infecton of the population or groups of individuals, the geometric mean of the epg was used. All slides were examined by the same technician.

\section{Interviews and treatment}

In the choice of variables, the associations found in other endemic areas were taken into account $2,7,10,12,13$, $15,18,20,21$.

The variables selected were divided into five groups: a) biological variables: age, sex, and previous treatment; b) environmental variables: locality, distance of the home from streams or ditches, presence of water in the home, method of fecal disposal; e) economic variables: profession and income; d) socio-cultural var-

TABLE 1

Prevalence of infection with Schistosoma mansoni by age in Barbosa and Peri-Peri (Capim Branco, MG), in 1991.

\begin{tabular}{lrrrrrr}
\hline \multirow{2}{*}{ Age } & \multicolumn{2}{c}{ Barbosa } & \multicolumn{2}{c}{ Peri-Peri } & $X^{2}$ & P \\
& p/e* & $(\%)$ & p $/ \mathbf{e}$ & $(\%)$ & & \\
\hline $0-4$ & $7 / 20$ & $(35.0)$ & $1 / 33$ & $(3.0)$ & 9.74 & 0.0018 \\
$5-9$ & $7 / 16$ & $(43.8)$ & $8 / 44$ & $(18.2)$ & 6.05 & 0.0139 \\
$10-19$ & $4 / 10$ & $(40.0)$ & $13 / 55$ & $(23.6)$ & 1.23 & 0.2671 \\
$20-29$ & $10 / 36$ & $(27.7)$ & $12 / 65$ & $(19.1)$ & 1.17 & 0.2796 \\
$\geqslant 30$ & $12 / 61$ & $(19.7)$ & $20 / 140$ & $(14.3)$ & 0.17 & 0.6771 \\
\hline Total & $40 / 143$ & $(28.4)$ & $54 / 337$ & $(16.0)$ & 8.15 & 0.0043 \\
\hline
\end{tabular}

* number of individuals in fected with $S$. mansoni amongst those examined. 
COURA-FILHO,P.; ROCHA, R. S.; FARAH,M. W.; SILVA, G. C. da \& KATZ, N. - Identification of factors and groups at risk of infection with Schistosoma mansoni: a strategy for the implementation of control measures? Rev. Inst. Med. trop. S. Paulo, 36 (3):245-253, 1994.

iables: migration, education, length of residence in the area; and e) behavioral variables: bathing for leisure and/or because of the lack of piped water in the home, collection of water, fishing, washing dishes and clothes, crossing streams, agricultural activities and the excavation of sand and minerals. Information concerning the independent variables was obtained by means of a questionnaire. Information relevant to children under seven was collected from the parent or guardian, usually the mother. The questionnaires were always completed without either the interviewer or the interviewer being aware of the results of the fecal examination (double blind). The interviewer was a previously trained student who had completed secondary education. The questionnaire was pre-tested with individuals from a different community in the same municipality with similar socioeconomic characteristics.

Treatment was given, after the completion of the interview, by doctors from the local health center. The schistosomicidal drug used was oxamniquine which was given in a single oral dose of $20 \mathrm{mg} / \mathrm{kg}$ for children and

TABLE 2

Risk of infection with Schistosoma mansoni in Barbosa (Capim Branco, MG) in 1991 according to socio-economic variables.

\begin{tabular}{|c|c|c|c|c|c|c|c|}
\hline \multirow{2}{*}{$\begin{array}{l}\text { Variables } \\
\text { 1. Age (years) }\end{array}$} & \multicolumn{2}{|c|}{$\begin{array}{l}\text { Infected } \\
(n=40) \%\end{array}$} & \multicolumn{2}{|c|}{$\begin{array}{l}\text { Not infected } \\
(n=103) \%\end{array}$} & \multicolumn{2}{|c|}{$\begin{array}{l}\text { Odds Ratio } \\
\text { (CI at } 95 \% \text { ) }\end{array}$} & \multirow[t]{2}{*}{$\mathrm{P}$} \\
\hline & & & & & & & \\
\hline$\leqslant 9$ & $(10)$ & 25.0 & (23) & 22.3 & 1.00 & & \\
\hline $10-19$ & (9) & 22.5 & (8) & 7.8 & 2.59 & $(0.66-10.38)$ & 0.1219 \\
\hline $20-29$ & $(10)$ & 22.5 & (32) & 31.1 & 0.65 & $(0.20-2.08)$ & 0.4168 \\
\hline$\geqslant 30$ & (14) & 30.0 & $(40)$ & 38.8 & 0.69 & $(0.23-2.06)$ & 0.4612 \\
\hline \multicolumn{8}{|c|}{$p=0.7203$} \\
\hline \multicolumn{8}{|l|}{ 2. Sex: } \\
\hline Female & $(20)$ & 50.0 & $(60)$ & 58.5 & 1.00 & & \\
\hline Male & $(20)$ & 50.0 & $(43)$ & 41.5 & 1.40 & $(0.63-3.10)$ & 0.4811 \\
\hline \multicolumn{8}{|c|}{ 3. Previous treatment: } \\
\hline No & (12) & 30.0 & (18) & 17.7 & 1.00 & & \\
\hline Yes & $(28)$ & 70.0 & $(85)$ & 82.8 & 2.02 & $(0.94-2.78)$ & 0.0999 \\
\hline \multicolumn{8}{|c|}{ 4. Distance from home to water source: } \\
\hline$\geqslant 10 \mathrm{~m}$ & $(19)$ & 47.5 & $(74)$ & 71.2 & 1.00 & & \\
\hline$<10 \mathrm{~m}$ & $(21)$ & 52.5 & $(29)$ & 28.2 & 2.82 & $(1.24-6.44)$ & 0.0348 \\
\hline \multicolumn{8}{|c|}{ 5. Drinking water in the home: } \\
\hline Yes & $(0)$ & 0.0 & $(0)$ & 0.0 & & & \\
\hline No & $(40)$ & 100.0 & $(103)$ & 100.0 & & & \\
\hline \multicolumn{8}{|c|}{ 6. Ilome without sewer direct to the river and/or latrine: } \\
\hline Yes & $(36)$ & 90.0 & (88) & 95.2 & 1.00 & & \\
\hline No & (4) & 10.0 & $(15)$ & 4.8 & 1.53 & $(0.43-5.90)$ & 0.3025 \\
\hline \multicolumn{8}{|l|}{ 7. Profession: } \\
\hline Others & $(28)$ & 70.0 & $(91)$ & 88.3 & 1.00 & & \\
\hline Agriculture & $(12)$ & 30.0 & $(12)$ & 11.7 & 3.25 & $(1.20-8.83)$ & 0.0170 \\
\hline \multicolumn{8}{|c|}{ 8. Family income, in terms of minimum salary: } \\
\hline$>3$ & $(29)$ & 72.5 & $(69)$ & 67.0 & 1.00 & & \\
\hline $0-3$ & (11) & 27.5 & (34) & 33.0 & 1.30 & $(0.54-3.15)$ & 0.5256 \\
\hline \multicolumn{8}{|l|}{ 9. Migrant: } \\
\hline No & $(20)$ & 50.0 & $(63)$ & 54.3 & 1.00 & & \\
\hline$<5$ years & (3) & 7.5 & (12) & 11.7 & 0.79 & $(0.16-3.46)$ & 0.7312 \\
\hline \multirow[t]{2}{*}{$\geqslant 5$ years } & $(17)$ & 42.5 & $(28)$ & 44.0 & 1.91 & $(0.81-4.51)$ & 0.1044 \\
\hline & & & & & & & \\
\hline \multicolumn{8}{|l|}{ 10. Education: } \\
\hline$\geqslant$ Secondary & (4) & 13.8 & $(7)$ & 8.8 & 1.00 & & \\
\hline Primary & $(17)$ & 58.6 & (59) & 72.0 & 0.58 & $(0.22-1.52)$ & 0.5242 \\
\hline \multirow[t]{2}{*}{ Illiterate } & (8) & 27.6 & (16) & 19.5 & 0.98 & $(0.34-2.78)$ & 0.8350 \\
\hline & & & & & & & \\
\hline \multicolumn{8}{|c|}{ 11. Type of home: } \\
\hline Better & $(36)$ & 90.0 & (88) & 85.4 & 1.00 & & \\
\hline Worse & (4) & 10.0 & (15) & 14.6 & 1.53 & $(0.43-5.90)$ & 0.6723 \\
\hline
\end{tabular}


COURA-FILHO, P.; ROCHA, R. S.;FARAH,M.W.; SILVA, G.C. da \& KATZ, N. - Identification of factors and groups at risk of infection with Schistosoma mansoni: a strategy for the implementation of control measures? Rev. Inst. Med. trop. S. Paulo, 36 (3):245-253, 1994.

TABLE 3

Risk of Schistosoma mansoni in Barbosa (Capim Branco, MG) in 1991 according to water use.

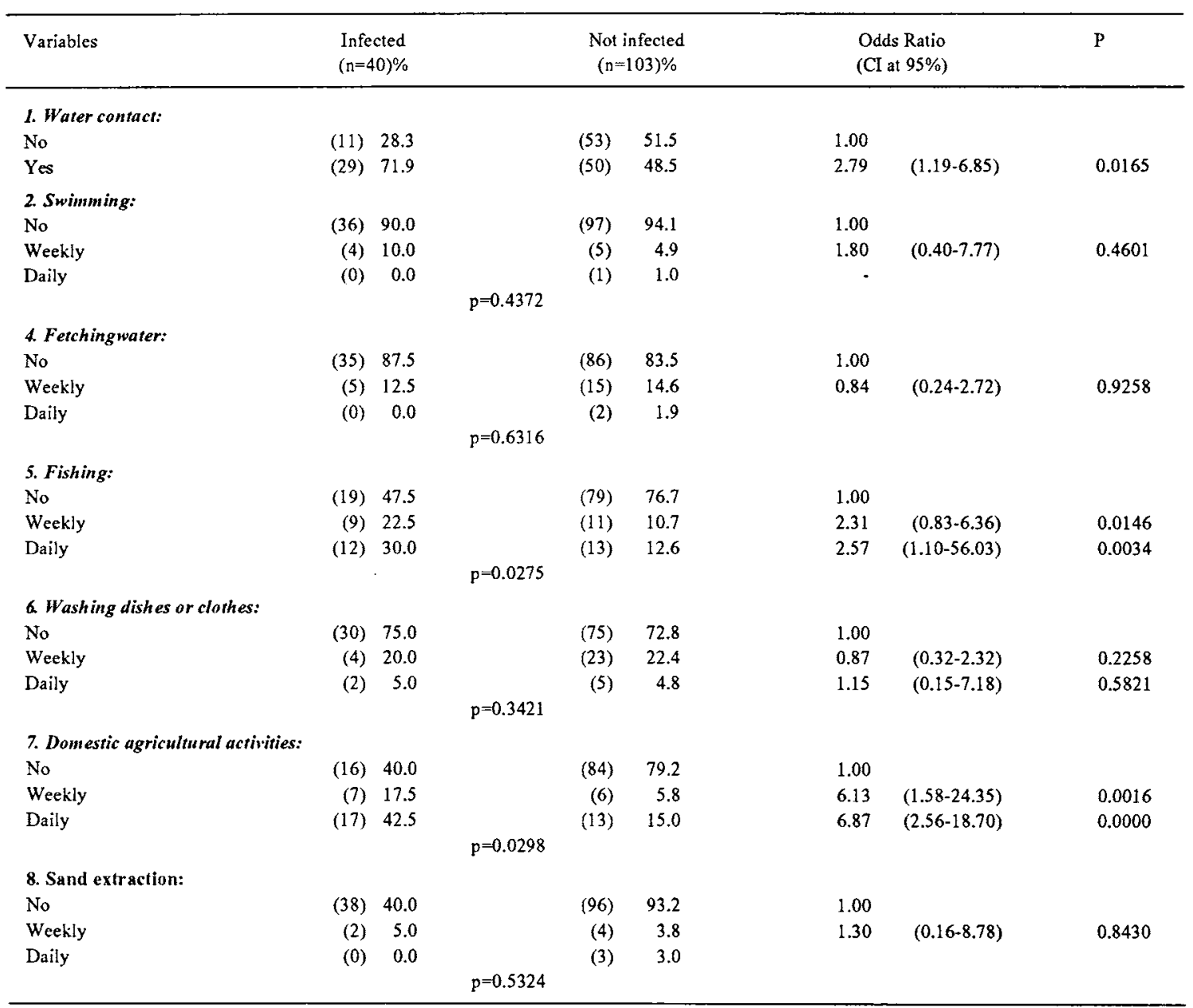

$15 \mathrm{mg} / \mathrm{kg}$ for adults is. The drug was taken in the presence of the prescribing physician. Interviews were undertaken after the treatment by physicians of the local health center.

\section{Data analysis}

Case-control was used for the identification of risk factors (independent variables) associated with schistosomiasis (dependent variable). Cases were considered as those individuals who were eliminating eggs in their feces. The controls were those not infected with $S$. mansoni (negative stool examination). The calculations of relative risk were obtained directly from the contigency tables in the statistical package Epi-Info ". The independent variables were analyzed for their statistical associations with the dependent variable using $X^{2}$. All the variables were submitted to multivariate analysis to eliminate confounding variables 1, 4, 11,17. A statistically significant association between the variables studied and schistosome infection was taken as $5 \%$. The methodology as described by LILIENFELD \& LILIENFELD (1981) ${ }^{19}$ was used in the determination of population attributable risk (PAR).

\section{RESULTS}

As can be observed in Table 1, in 1991 prevalence in the rural area was significantly higher than in the urban area $\left(X^{2}=8.15, p=0.0043\right)$, in children of $0-4$ years $\left(X^{2}=9.74\right)$ and 5-9 years $\left(X^{2}=6.05\right)$. The intensity of infection was similar in the two areas and was not age associated. 
The univariate analysis indicated that the risk factors associated with infection in the rural area (Barbosa) were: residence less than 10 meters from an irrigation ditch or stream [Odds Ratio $=2.82(1.24-6.44)$ ], employment in agriculture [OR $=3.25(1.20-8.83)]$ (Table 1), fishing everyday $[\mathrm{OR}=2.57(1.10-56.03)]$ and domestic agricultural activities, weekly $[\mathrm{OR}=6.13(1.58-24.35)]$ or daily $[O R=6.87(2.56-18.56)]$ (Tables 2 and 3$)$. In the urban area the risk factors were; residence less than 10 meters from an irrigation ditch or stream [OR $=2.94$
(1.52-5.67)], absence of drinking water in the home [(OR $=5.87(1.75-19.71)]$, home without drains connected to the stream and/or latrine $[O R=3.84$ (1.84-10.18)], family income of less than three minimum salaries [OR = $0.23(0.12-0.44)]$, being a recent migrant [OR $=2.63$ $(1.08-6.50)]$, worse housing [OR $=9.21(4.60-18.66)]$, swimming weekly $[O R=2.26(1.18-4.33)]$ and daily $[O R$ $=0.10(0.02-1.43)]$, fishing weekly $[\mathrm{OR}=3.01(1.10$ $8.12)]$ and daily domestic agricultural activity $[\mathrm{OR}=$ 4.30 (1.26-14.44)] (Tables 4 and 5).

TABLE 4

Risk of infection with Schistosoma mansoni in Peri-Peri (Capim Branco. MG) in 1991 according to socio-economic variables.

\begin{tabular}{|c|c|c|c|c|c|c|c|}
\hline $\begin{array}{l}\text { Variables } \\
\text { 1. Age (years) }\end{array}$ & \multicolumn{2}{|c|}{$\begin{array}{l}\text { Infected } \\
(n=54) \%\end{array}$} & \multicolumn{2}{|c|}{$\begin{array}{l}\text { Not infected } \\
(\mathrm{n}=283) \%\end{array}$} & \multicolumn{2}{|c|}{$\begin{array}{l}\text { Odds Ratio } \\
\text { (CI at } 95 \%)\end{array}$} & \multirow[t]{2}{*}{$\mathrm{P}$} \\
\hline$\leqslant 9$ & $(10)$ & 18.5 & $(68)$ & 24.0 & 1.00 & & \\
\hline & (15) & 27.8 & (46) & 16.3 & & & \\
\hline $20-29$ & (13) & 24.1 & $(54)$ & 19.1 & 1.34 & $(0.64-2.81)$ & 0.2810 \\
\hline$\geqslant 30$ & (16) & 29.6 & (115) & 40.6 & 0.62 & $(0.31-1.20)$ & 0.9297 \\
\hline \multicolumn{8}{|c|}{$p=0.1164$} \\
\hline \multicolumn{8}{|l|}{ 2. Sex: } \\
\hline Female & $(22)$ & 40.7 & $(142)$ & 49.8 & 1.00 & & \\
\hline Male & (32) & 59.3 & (141) & 50.2 & 1.46 & $(0.78-2.76)$ & 0.2049 \\
\hline \multicolumn{8}{|c|}{ 3. Previous treatment: } \\
\hline No & (16) & 29.6 & $(81)$ & 28.6 & 1.00 & & \\
\hline Yes & $(38)$ & 70.4 & $(202)$ & 71.4 & 1.05 & $(0.53 \cdot 2.07)$ & 0.8810 \\
\hline \multicolumn{8}{|c|}{ 4. Distance from home to water source: } \\
\hline$\geqslant 10 \mathrm{~m}$ & $(31)$ & 57.4 & $(226)$ & 79.9 & 1.00 & & \\
\hline$<10 \mathrm{~m}$ & (23) & 42.6 & (57) & 20.1 & 2.94 & $(1.52-5.67)$ & 0.0000 \\
\hline \multicolumn{8}{|c|}{ 5. Drinking water in the home: } \\
\hline Yes & $(47)$ & 87.0 & $(276)$ & 97.8 & 1.00 & & \\
\hline No & $(7)$ & 13.0 & (7) & 2.2 & 5.87 & $(1.75-19.71)$ & 0.0004 \\
\hline \multicolumn{8}{|c|}{ 6. Residence without sewer } \\
\hline Yes & $(45)$ & 83.3 & $(269)$ & 95.1 & 1.00 & & \\
\hline No & (9) & 16.7 & (14) & 4.9 & 3.84 & $(1.84-10.18)$ & 0.0017 \\
\hline \multicolumn{8}{|l|}{ 7. Profession: } \\
\hline Others & (34) & 62.9 & $(205)$ & 72.7 & 1.00 & & \\
\hline Agriculture & $(20)$ & 37.1 & (78) & 27.3 & 1.55 & $(0.80-2.97)$ & 0.1606 \\
\hline \multicolumn{8}{|c|}{ 2. Family income, in terms of minimum salary: } \\
\hline$>3$ & (35) & 64.8 & (84) & 29.7 & 1.00 & & \\
\hline $0-3$ & (19) & 35.2 & (199) & 70.3 & 0.23 & $(0.12-0.44)$ & 0.0000 \\
\hline \multicolumn{8}{|l|}{ 9. Migrant: } \\
\hline No & $(10)$ & 18.5 & $(120)$ & 42.4 & 1.00 & & \\
\hline$<5$ years & (18) & 33.3 & $(82)$ & 30.0 & 2.63 & $(1.08-6.50)$ & 0.0180 \\
\hline \multirow[t]{2}{*}{$\geqslant 5$ years } & (26) & 48.2 & $(81)$ & 27.6 & 3.85 & $(1.67-9.09)$ & 0.0004 \\
\hline & \multicolumn{4}{|c|}{$p=0.0020$} & & & \\
\hline \multicolumn{8}{|c|}{ 10. Education: } \\
\hline$\geqslant$ Secondary & (12) & 24.5 & $(35)$ & 15.7 & 1.00 & & \\
\hline Primary & $(25)$ & 51.0 & $(177)$ & 76.7 & 0.31 & $(0.15-0.61)$ & 0.0227 \\
\hline \multirow[t]{2}{*}{ Illiterate } & (12) & 24.5 & (17) & 7.6 & 4.04 & $(1.65-9.84)$ & 0.1515 \\
\hline & \multicolumn{4}{|c|}{$p=0.1012$} & & & \\
\hline \multicolumn{8}{|c|}{ 11. Type of home: } \\
\hline Better & (16) & 29.7 & (225) & 79.5 & 1.00 & & \\
\hline Worse & (38) & 70.3 & $(58)$ & 20.5 & 9.21 & $(4.60-18.66)$ & 0.0000 \\
\hline
\end{tabular}


COURA-FILHO, P.;ROCHA,R. S.; FARAH, M. W.; SILVA, G.C. da \& KATZ, N. - Identification of factors and groups at risk of infection with Schistosoma mansoni: a strategy for the implementation of control measures? Rev. Inst. Med. trop. S. Paulo, 36 (3):245-253, 1994.

TABIE 5

Risk of infection with Schistosoma mansoni in Peri-Peri (Capim Branco, MG) in 1991 according to socio-economic variables.

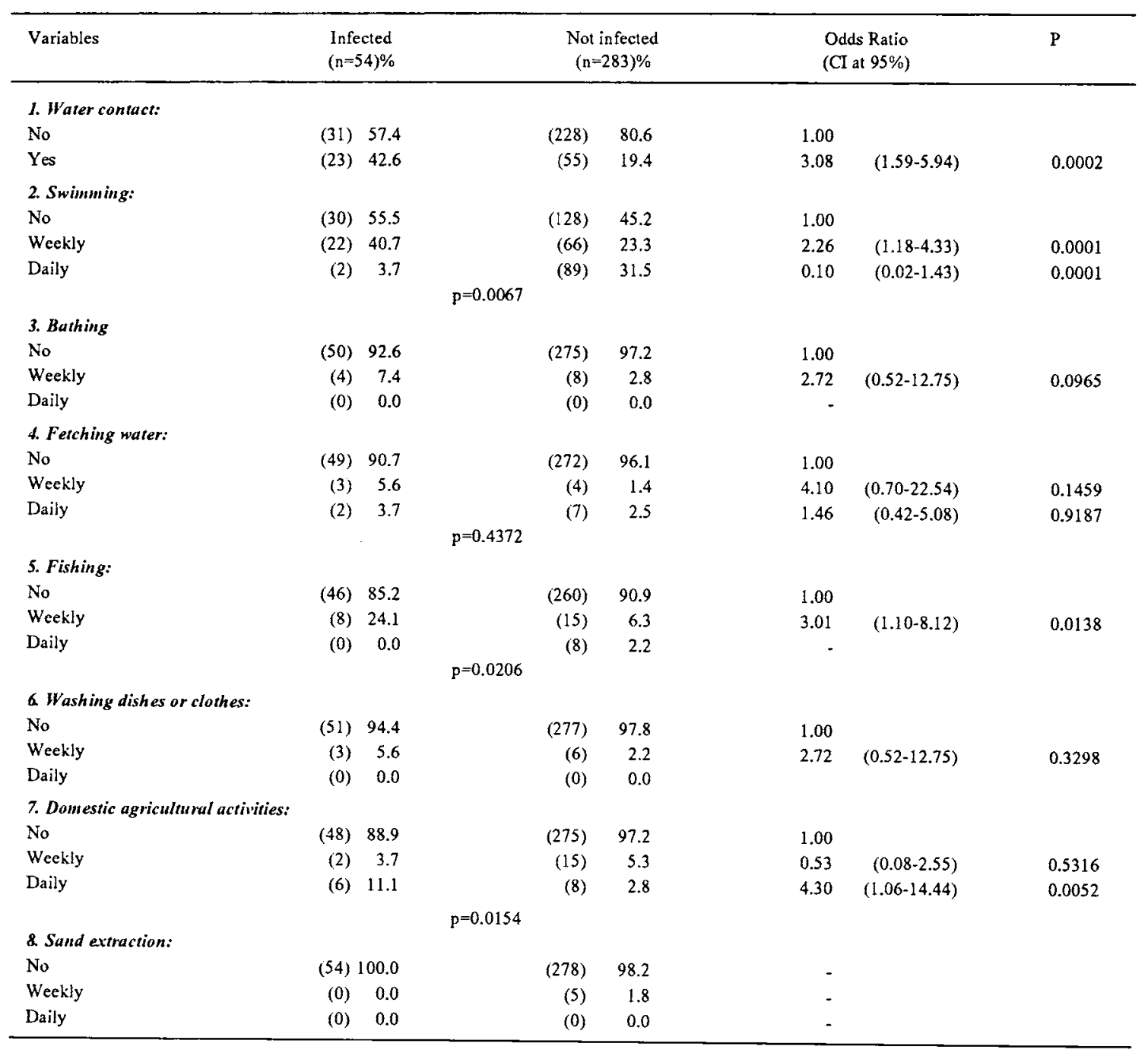

The multivariate analysis undertaken to identify independent factors associated with $S$. mansoni infection showed that in the rural area residence of less than 10 meters from an irrigation ditch or stream [OR $=2.18(1.05-6.66)]$, weekly fishing $[O R=3.29$ $(1.26-8.40)]$ and daily domestic agricultural activity $[\mathrm{OR}=3.35(1.02-7.01)]$ (Table 6) (Table 7). In the urban area, daily domestic rural activity $[O R=3.23$ (1.49-8.31)], lack of drinking water in the home [OR $=2.16(1.04-9.56)]$ and weekly swimming $[O R=3.32$ (1.03- 7.47)] (Table 6) are responsible for infections (Table 7).

\section{DISCUSSION AND CONCLUSIONS}

Both in the urban and rural areas studied here the practice of domestic agriculture appeared as a risk factor for infection. The necessity of food suplementation and/ or agricultural habits result in the population having contact with $S$. mansoni cercariae thus contributing to the maintenance and urbanization of the disease $2,22,24$. A similar profile was identified on the urban periphery of São Paulo, where horticulture, both commercial and domestic, had an important role in the establishment of new endemic foci ${ }^{24}$. Another factor that contributes to 
COURA-FILHO, P.; ROCHA, R. S.;FARAH, M. W.; SLVA, G. C. da \& KATZ, N. - Identification of factors and groups at risk of infection with Schislosoma mansonit a strategy for the implementation of control measures? Rev. Inst. Med. trop. S. Paulo, 36 (3):245-253, 1994.

TABLE 6

Multivariate analysis of risk factors for infection by Schistosoma mansoni in Barbosa and Peri-Peri (Capim Branco, MG), 1991.

\begin{tabular}{|c|c|c|c|c|c|c|}
\hline \multirow[t]{2}{*}{ Variables } & \multicolumn{3}{|c|}{ Barbosa } & \multicolumn{3}{|c|}{ Peri-Peri } \\
\hline & OR & (CI at $95 \%)$ & $p$ & OR & (CI at $95 \%)$ & $\mathrm{p}$ \\
\hline $\begin{array}{l}\text { 1. Distance of home from } \\
\text { water source } \leqslant 10 \mathrm{~m}\end{array}$ & 2.18 & $(1.05-6.66)$ & 0.0079 & & - & \\
\hline 2. Fishing weekly & 3.29 & $(1.26-8.40)$ & 0.0031 & & - & \\
\hline $\begin{array}{l}\text { 3. Undertaking domestic } \\
\text { agricultural activity daily }\end{array}$ & 3.35 & $(1.02-7.01)$ & 0.0051 & 3.23 & $(1.49-8.31)$ & 0.00 \\
\hline $\begin{array}{l}\text { 4. Absence of drinking water } \\
\text { in the home }\end{array}$ & & - & & 2.16 & $(1.04-9.56)$ & 0.00 \\
\hline 5. Swimming Weekly & & - & & 3.32 & $(1.03-7.47)$ & 0.00 \\
\hline
\end{tabular}

$\mathrm{OR}=$ Odds ratio $\mathrm{CI}=$ confiance interval

the urbanization of schistosomiasis is the lack of leisure options for the population with lower income. In the summer individuals seek out waterfalls, lakes, rivers and even streams for leisure.

The urbanization of endemic diseases in large urban centers can be explained on the basis of the poor sanitary condition that exists on the periphery which are frequently worse than in rural areas ${ }^{22}$.

The determination of the PAR for each factor associated with infection allows the identification of which factors, if removed, would contribute most to the prevention of infection. In the rural area the use of
PAR identified the measure that would prevent the largest number of infections (29.93\%) as being the diversion of streams that pass less than 10 meters to residences. This measure would prevent $35.0 \%$ of infections in children of $0-4$ years who habitually play catching fish in streams close to the home. This measure was not permitted by the community as the presence of water close to the home is considered to increase the value of the property and also because it is the only source of irrigation for horticulture which provides the income for $52.5 \%$ of the working population. The possibilify of industrial irrigation is being evaluated by the Town Council and farmers, although is more difficult to undertake due to cost.

TABLE 7

Population attributable risk (PAR) for Schistosoma mansoni in Barbosa and Peri-Peri (Capim Branco, MG), in 1991.

\begin{tabular}{|c|c|c|c|c|}
\hline Locality & factors & Odds Ratio & $\begin{array}{l}\text { Proportion of factor } \\
\text { in the population }\end{array}$ & $\begin{array}{c}\text { Population attributable } \\
\text { risk PAR-\% ** }\end{array}$ \\
\hline \multirow[t]{3}{*}{ Barbosa } & $\begin{array}{l}\text { - Undertaking domestic } \\
\text { agricultural activity daily }\end{array}$ & 3.35 & 0.210 & 29.82 \\
\hline & $\begin{array}{l}\text { - Distance of home from } \\
\text { water source } \leqslant 10 \mathrm{~m}\end{array}$ & 2.18 & 0.349 & 25.93 \\
\hline & - Fishing weekly & 3.29 & 0.139 & 17.21 \\
\hline \multirow[t]{3}{*}{ Peri-Peri } & Swimming weekly & 3.32 & 0.261 & 20.71 \\
\hline & $\begin{array}{l}\text { Absence of drinking water } \\
\text { in the home }\end{array}$ & 2.16 & 0.042 & 4.29 \\
\hline & $\begin{array}{l}\text { - Undertaking domestic } \\
\text { agricultural activity daily }\end{array}$ & 3.23 & 0.042 & 4.07 \\
\hline
\end{tabular}

$\begin{gathered}\text { No. of cases } \\ \text { examinated }\end{gathered} \quad * * P A R=\frac{p(O R-1)}{1+p(O R-1)}$


COURA-FILIHO,P.; ROCHA, R. S.; FARAH,M. W.; SIL VA, G. C. da \& KATZ, N. - Identification of factors and groups at risk of infection with Schistosoma mansoni: a strategy for the implementation of control measures? Rev. Inst. Med. trop. S. Paulo, 36 (3):245-253, 1994.

In the urban area the most frequent PAR was weekly swimming (PAR=20.12\%) followed by absence of drinking water in the home which was responsible for $4.29 \%$ of infections and daily domestic agricultural activity $(4.01 \%)$. The offering of leisure options for the urban population and the provision of a domeslic water supply were the indicated courses of action. Discussions are taking place between the Residents Association, the Amateur Football Club, local firms and the Town Council concerning the construction of a swimming pool and sports facilities. Indeed, the community received as a donation a piece of land belonging to a textile company for the construction of a leisure area in collaboration with the Amateur Football Club.

In the areas studied, the persistence of the transmission of schistosomiasis is explained on the basis of well known risk factors such as lack of sanitation, agricultural activities in water with cercariae and recreation. It can be seen that the multivariate analysis confirmed by means of a sophisticated analysis the presence of risk factors which have been previously been identified by means of direct observalion of the habits and customs of individuals in natural water in endemic areas.

Nevertheless, the use of multivariate analysis for the identification of risk factors for schistosome infection on a large scale may be difficult because: a) the need for extensive knowledge of epidemiology by appropriately able individuals in the relevant basic health network (which does not occur frequently); b) computer equipment that is not normally available in the basic health network; c) the necessity of its efficacy being evaluated in terms of the identification of risk factors and the implantation of the preventive measures and control and d) the low level of capacity of the health services in undertaking the measures defined by the risk factors.

In addition to the operational problems, the fact that the method considers all the factors as being static and of equal importance in the transmission of the disease, without taking into account the real importance of each factor in the daily life of the community, is also limiting. Other problems are the possibility of factors that are collinear with others and which are not included in the multivariate analysis and this method does not identify individuals who undertake various activities in water infested with cercariae, thus running an appreciably higher risk than those individuals who undertake a single type of activily.
In conclusion, although the identification of risk factors seems to be a valuable methodology for the indication of measures for schistosomiasis control, this must be demonstrated in practice before its large scale use be recommended.

\section{RESUMO}

\section{Identificação de fatores e grupos de risco de infeç̧ão com Schistosoma mansoni: Uma estratégia para implementação de medidas de controle?}

Um programa de controle da esquistossomose mansoni em Peri-Peri, (Capim Branco, MG), durante catorze anos reduziu a prevalência de 43,5 para $4,4 \%$; a incidência de 19,0 para 2,9\%: a média geométrica do número de ovos de 281 para 87 e o indice da forma hepatoesplênica de 5,9 para $0,0 \%$. Em 1991, após três anos de interrupção do programa, a prevalência subiu para $19,6 \%$. Neste distrito que é formado pelas localidades de: Barbosa (rural) e Peri-Peri propriamente dita (urbana), em 1991, as prevalências foram respectivamente de $28,4 \%$ e $16,0 \%$. A análise multivariada de fatores de risco para a infecção esquistosomótica apontou a atividade agrícola peridomiciliar com risco atribuivel populacional (RAP) de $29,93 \%$, a distância $(\leqslant 10 \mathrm{~m}$ ) da residência à fonte de água natural $(\mathrm{RAP}=25,93 \%)$ e pescar semanalmente $(\mathrm{RAP}=17,21 \%)$ como sendo responsáveis por infeç̧ões na área rural. As medidas de controle apontadas para esta área foram: irrigação não artesanal e afastamento das valas de irrigação para mais de dez metros das residências. Na urbana, foi observado que nadar semanalmente $(\mathrm{RAP}=20,71 \%)$, exercer atividade agrícola peridomiciliar diariamente $(\mathrm{RAP}=$ $4,07 \%$ ) e não ter água potável intradomiciliar (RAP = $4,29 \%$ ) foram responsáveis por infecções.

Para a área urbana as medidas apontadas foram criar opções de lazer para a população, substituir a irrigação artesanal por outro tipo que evite o contato com águas $\mathrm{e}$ fomecer água potável intradomiciliar. Observa-se que na área rural o RAP dominante foi devido a atividade agrícola peridomiciliar diária e na urbana, nadar por lazer. Os autores chamam a atenção para a necessidade de se avaliar a eficácia da técnica de análise de fatores de risco para esta endemia antes de usá-la em larga escala como indicador de medidas de controle.

\section{ACKNOWLEDGEMENT}

The authors are indebted to Dr. Andrew J. G. 
Simpson for the language corrections, to Departamento de Grandes Endemias "Samuel Pessoa"/ENSP/ FIOCRUZ for the suggestions, and to Dr. Dilermando Fazito de Resende for the help in the statisticals analysis.

\section{REFERENCES}

1. ARMITAGE, P. - Statistical method in medical research. Oxford, Blackwell, 1977.

2. BARRETO, L. C. - Epidemiology of urban schistosomiasis mansoni in northeast Brazil. A case study in Santo Antônio de Jesus. London, 1986. (Doctor Thesis - University of London).

3. BINA, J. C. - Influência da terapêutica especifica na evolução da esquistossomose. Salvador, 1977. (Tese de Mestrado - Faculdade de Medicina da Universidade Federal da Bahia).

4. CAMPOS-FIL HO, N. B. S. \& FRANCO, E. F. - A microcomputer program for multiple logistic regression by unconditional and conditional maximum likelihood methods. Amer. J. Epidem., 129: $439-444,1989$.

5. CHANDIWANA, S. K. - Antischistosomiasis in a community of high transmission. Trop. geogr. Med., 40: 413-417, 1988.

6. COURA-FILHO, P. - Avalią̧ão de um programa municipalizado de controle de esquistassomase mansoni em Peri-Peri (Capim Branco) MG (Brasil). Belo Horizonte, 1990. (Tese de Mestrado - Faculdade de Medicina Veterinária da Unoiversidade Federal de Minas Gerais).

7. COURA-FILHO, P.; ROCHA, R. S. \& KATZ, N. - Estudo do contato com águas naturais em uma população de área endêmica de esquistossomose em Minas Gerais. In: CONGRESSO DA SOCIEDADE BRASILEIRA DE PARASITOLOGIA, 21., Fortaleza, 1985. Anais. p. 73.

8. COURA-FLLHO, P.; MENDES, N. M.; SOUZA, C. P. \& PEREIRA, J. P. - The prolonged use of niclosamide as a molluscicide for the control of Schistosoma mansoni. Rev. Inst. Med. trop. S. Paulo., 34: 427-431, 1992.

9. COURA-FILHO, P.; ROCHA, R. S.; LIMA E COSTA, M. F. F. \& KATZ, N. - A municipal level approach to the management of schistosomiasis control in Peri-Peri, MG - Brazil. Rev. Inst. Med. trop. S. Paulo., 34: 543-548, 1992.

10. CURI, G. C. - Estudo clinico-epidemiológico da esquistossomose mansoni em Comercinho, Minas Gerais (1974, 1981 e 1988). . Belo Horizonte, 1992. (Tese de Doutoramento - Universidade Federal de Minas Gerais).

11. DEAN, A. G.; DEAN, J. A.; BURTON, A. H. \& DIKER, R. C. - Epi Info Version 5: a word processing, database, and statistics program for epidemiology on microcomputers. Atlanta, GA, Centros de Lucha contra las Enfermedades, 1990.

12. GUERRA, H. - Epidemiologia da esquistossomose mansoni em São José do Acácio, MG. Análise multivariada dos fatores associados à infeç̧ão. Variáveis sócio-demográficas e contatos com águas naturais. Belo Horizonte, 1992. (Tese de Mestrado - Faculdade de Medicina Veterinária da Universidade Federal de Minas Gerais).

13. GUIMARÃES, M. D. C.; LIMA E COSTA, M. F. F.; LIMA, L. B. \& MOREIRA, M. A. - Estudo clínico-epidemiológico da esquistossomose mansoni em escolares da Iha, Municipio de Arcos, MG (Brasil). Rev. Saúde públ. (S. Paulo), 19: 8-17, 1985

14. KATZ, N.; CHAVES, A. \& PELLEGRINO, J. - A simple device for quantitative stool thick-smear tecnique in schistosomiasis mansoni. Rev. Inst. Med. trop. S. Paulo, 14: 397-400, 1972.

15. KATZ, N.; ROCHA, R. S. \& PEREIRA, J. P. - Controle da esquistossomose em Peri-Peri (Minas Gerais) através de repetidos tratamentos clínicos e aplicações de moluscicida. Rev, Inst. Med. trop. S. Paulo, 22 (supl. 4): 203-211, 1980.

16. KATZ, N.; ZICKER, F.; ROCHA, R. S. \& OLIVEIRA, V. B. Reinfection of patients in schistosomiasis mansoni endemic areas after specific treatment. I. Influence of age and worm burden. Rev. Inst. Med. trop. S. Paulo, 20: 273-278, 1978.

17. KERLINGER, F. N. - Metodologia da pesquisa em ciências sociais: un tratamento conceitual. 2. ed. São Paulo, Pedagógica e Universitária, 1979.

18. KLOETZEL, K. - Alguns novos conceitos sobre epidemiologia da esquistossomose. IIospital (Rio de J.), 75: 33-44, 1969.

19. LILIENFELD, A. M. \& LILIENFELD, D. E. - Fundamentations of Epidemiology. 2. ed. New York, Oxford University Press, 1981.

20. LIMA E COSTA, M. F. F.; MAGALHÃES, M H. A.; ROCHA, R. S.; ANTUNES, C. M F. \& KATZ, N. - Water contact patterns and socio economic variable in the epidemiology of schistosomiasis mansoni in an endemic area in Brazil. Bull. Wld. Hith. Org., 65: $57-66,1987$.

21. LIMA E COSTA, M. F. F.; ROCHA, R. S.; LEITE, M. L. C. et al. A multivariate analysis of socio-demographic factors, water contact patterns and Schistosoma mansoni infection in an endemic area in Brazil. Rev. Inst. Med. trop. S. Paulo, 33: 58-63, 1991.

22. MOTT, K.; DESJEUX, P.; MONCAYO, A.; RANQUE, P. \& RAADT, de P. - Parasitic diseases and urban development. Bull. Wh. HIht. Org., 68: 691-698, 1990.

23. SANTOS, M. L. \& COURA, J. R. - Morbidade da esquistossomose no Brasil. IV. Evolução em pacientes tratados e seus controles. Mem. Inst. Oswaldo Cruz, 81: 53-60, 1986.

24. SILVA, L. J. - Crescimento urbano e doença: a esquistossomose no município de São Paulo (Brasil). Rev. Saúde públ. (S. Paulo), 19: $1-7,1985$.

25. SOMARRIBA, M M. G.; VALADARES, M. G. \& AFONSO, M. R. - Lutas urbanas. Petrópolis, Vozes, 1984.

Recebido para publicação em 21/10/1993. Aceito para publicação em 01/02/1994. 